\title{
Toward a Formula-Based Model for Academic Library Funding: Statistical Significance and Implications of a Model Based upon Institutional Characteristics
}

\author{
Frank R. Allen and Mark Dickie
}

This study tests the hypothesis that a positive relationship exists between academic library funding (dependent variable) and selected institutional variables taken as indicators of the demand for library services at the university (enrollment, number of doctoral programs, doctoral degrees awarded, number of faculty, select other institutional characteristics). The research employs 11 years of longitudinal data from 113 members of the Association of Research Libraries to create a multiple regression model. Empirical results indicate that operational indicators of the demand for library services are positively associated with funding, and most of the associations are statistically significant at the five percent level or less in two tail tests. In a corollary finding, libraries associated with private universities in the United States spend 21 percent more than their public counterparts, while Canadian university libraries spend 21 percent less than U.S. public university libraries. The presence of a medical school is associated with an 8.6 percent greater expenditure, and the presence of a law school is associated with a 12.3 percent greater expenditure.The study suggests that this formula may be useful as a tool for library funding and assessment of adequacy of library budgets.

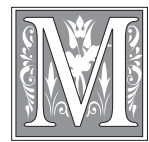

any academic libraries in the United States have traditionally experienced funding in an incremental or haphazard fashion. This served libraries adequately until the latter two decades of the 20th century. The challenge in recent years has been to find a model to support the sea change of issues facing academic libraries, including serials inflation, new technology initiatives, growth in academic degree programs, and changing usage patterns. Models that may have worked decades ago and models that may be effective in our universities at large no longer serve libraries. How does the 21st-century

Frank R. Allen is Associate Director for Administrative Services, University of Central Florida Libraries, and Mark Dickie is Professor, Department of Economics, College of Business Administration, at the University of Central Florida; e-mail: fallen@mail.ucf.edu and Mark.dickie@bus.ucf.edu, respectively. 
academic library petition for funds? What new funding models can libraries employ? What benchmarks are used to determine if a library is adequately funded? Where can we go to identify other models that might serve academic libraries?

Subjective funding mechanisms for libraries can impair short- and long-term planning. How can a library director or collection manager make informed resource allocation decisions when there is little predictability for the materials budget? Funding uncertainties are exacerbated by the explosion of published literature, packaged deals that encourage libraries to buy what they do not need, and redundancy of content format. It is impossible to know when the library is adequately funded because there is no defined target toward which to aim. Libraries may benefit from an element of objectivity worked into the funding mechanism, one that would center the task of allocating dollars to the library. The library might then be more resigned to going about the business of allocating its scarce economic resources internally, knowing that at least it got its share of the university pie.

It is the thesis of this study that the library's budget should be more program driven and less susceptible to the economic and political vagaries of the institution. A formula-based budget may provide more stability and render the library less vulnerable to disproportionate cuts. A program-driven budget may reinforce the notion of the library as an academic as opposed to an administrative campus unit. Many libraries do not have much traction when negotiating for funding. A program-driven approach may build in growth drivers based upon the health of the institution as a whole. The economic well-being of the library would rise and fall along with the larger university.

\section{Literature Survey}

Few published studies address funding mechanisms for the academic library as a whole. It is important to distinguish between models for funding of the entire library (the focus of this study) versus models for the allocation of the materials budget, not the focus of this study. In a 1992 article, David Baker revealed findings from a survey on resource allocation in university libraries in the United Kingdom. His major conclusions were that there is a movement toward using formulae and unit costs as the basis of allocation of central (state) funds to universities; however, there is little sign that such approaches are being adopted by universities once the funds are received. He found virtually no evidence of a formula approach to the method of funding university libraries. ${ }^{1}$ In a 1993 article, Frank Goudy presented data from 1971 to 1990 to show that the ACRL Libraries standard that the library's appropriation shall be 6 percent of total institution budget has never been realized. According to Goudy, the " $6 \%$ rule" was wishful thinking that never existed. ${ }^{2}$ The authors note that ACRL subsequently dropped this standard, relying on a more generalized statement that the library budget should be appropriate to the library's objectives. (See: www.ala.org/ ala/acrl/acrlstandards/standardslibraries. htm. $)^{3}$ Kendon Stubbs lamented in a 1994 study the decline in research libraries' share of university funds. Based upon survey data from 88 ARL libraries, the percentage of university E\&G funds allocated to these libraries fell steadily from 3.91 percent in 1982 to 3.32 percent in 1992 . He postulated several causes for this decline, but did not discuss funding formulas. ${ }^{4}$ Rolf Griebel discussed in a 1995 examination of German university libraries a financial approach known as the "Bavarian Model Budget." The model uses a methodology that identifies the tier to which a library and university belong and then specifies what percentage of newly published literature a library in this tier should purchase. He concluded that German libraries are underfunded by approximately 30 percent, according to this model. ${ }^{5}$ In a 1996 opinion paper, Murle Kenerson criticized formulas that the Tennessee Higher Education Commission (THEC) uses for the distribution of monies to support higher education in Ten- 
nessee, including academic libraries. The formulas incorporate full-time equivalent (FTE) enrollment and performance-based approaches using student test scores and placement of graduates. Kenerson argued that FTE may be appropriate for funding of classroom instruction; but, at the author's home institution of Tennessee State University, "half-time" students may require as many library resources as full-time students. "Grade point averages, improved test scores and similar mechanisms are of little consequence in assessing the real value of library services and in securing a fair share of performance funding dollars." Kenerson found that even when the library was allocated a certain stated amount of funding in the university budget, the full sum was never received by the library. ${ }^{6}$ In a 1999 article Jin-Chuan Ma argued that Chinese university libraries are slipping behind in their ability to support their institutions' research agenda. Ma suggested that, in addition to receiving 5 percent of the university's operational budget, the current model, university libraries should also receive a percentage of the university's research and grant funding, to be used for acquisition of information resources to support that research. ${ }^{7}$

Libraries are somewhat of a microcosm of a university, with large staffing, operational, and program-driven costs. It may be of interest to look at the literature on funding mechanisms of universities as a whole. The picture here is also somewhat muddled. In a 2002 article, Peter Facione likened the fiscal process of most American colleges and universities to the "controlled economy approach" used by the former Soviet Union. Central committees project income and expenses, establish strict guidelines for expenditures of resources, and take back unexpended balances at year's end. This approach does little to reward strategic planning, program review, and new program development. ${ }^{8}$ In a 1985 paper, Jim Tolhurst discussed resource allocation and budgeting in U.K. and Australian universities. He reported on an earlier U.K. study that summarized university funding practices as routinely employing: (1) little relationship between long-term objective and resource allocation; (2) allocation of resources based upon incremental allocation from an historical base; (3) a division of resources between the academic and nonacademic sectors based upon historical cost-share basis; (4) resource allocation that does not appear to take into account the relative strengths of departments. ${ }^{9}$ In a 2003 article, Nancy Cantor and Paul Courant discussed recent trends in higher education finance that carry disquieting consequences. The use of "bottom-line departmental budgeting" in which units retain the revenues associated with their activities, but are also responsible for the costs of those activities, works to the detriment of university "public goods," a prime example of which is the university library. Public goods such as the library are vulnerable under this model because it is often difficult to establish an exact return on their investment, yet their presence is thought to have a significant impact on the intellectual and cultural well-being of the community as a whole. ${ }^{10}$ In a 2003 paper, Gunapala Edirisooriya advocated an entirely new approach to funding of higher education in the United States. The author's premise was to create a reserve for higher education by reducing the amount of funding for higher education by $\mathrm{X} \%$ per year, beginning far enough out to allow universities to prepare, and increasing this percentage each year until a sizable reserve is established. The reserve is then used to provide a stable source of revenue for both the state and higher education. ${ }^{11}$

In summary, there appear to be few published models for academic library funding. Furthermore, of the few to be postulated, some of those have not been applied. At least two studies have commented upon the decline of academic library funding in the United States as a percentage of university funding, which one might argue gives further impetus for this study. The literature also reveals a concern at a larger level over university funding mechanisms, suggesting that most are short on objective 
rigor and long on political influence or incrementalism. One example of a novel budgeting technique, responsibility-centered management, is a move in an interesting direction but denudes the library to an administrative support function devoid of academic mission.

\section{Hypothesis and Methodology}

The purpose of this study is to illustrate a model in which funding of an academic library depends on institutional characteristics. The model assumes that the funding an academic library receives is influenced partly by the demand for the library's services from the university's students, faculty, and programs. One reason for adopting this assumption is to explore the plausibility of a model that relies on variables external to the library as drivers of funding. This represents a significant departure from arguments that the library's funding, or more specifically petitions for increases in funding, be predicated upon its existing size, holdings, serials inflation - in essence, inertia.

To implement the model empirically, we turn to the annual statistical survey of the Association of Research Libraries (ARL) as the source for operational indicators of the theoretical construct "demand for the library's services from students, faculty, and programs." Specifically, we use X1 $=$ undergraduate enrollment to indicate demand from undergraduate students; $\mathrm{X} 2$ = graduate enrollment and X3= number of Ph.D. degrees awarded annually to reflect demand from graduate students; $\mathrm{X} 4=$ number of teaching faculty to indicate demand from faculty; $X 5=$ number of Ph.D. fields, X6 = presence of medical school $(1$ if present, 0 if not), and $X 7=$ presence of law school ( 1 if present, 0 if not) to reflect demand from graduate and relatively expensive professional programs of the university. Although these variables are imperfect measures of the theoretical construct and, as discussed in more detail later, there are other potential determinants of library funding that might usefully be considered in future research, the variables selected represent measurable indicators of institutional characteristics related to the demand for library services.

Our research hypothesis is that a positive relationship exists between total library expenditures (dependent variable - Y) and the independent variables just described (X1 through X7).We use multiple regression to quantify this relationship. Recognizing that there may be systematic differences in funding between private and public institutions in the U.S. and Canadian institutions, we include two additional qualitative independent variables: X8 = U.S. private university (1 if U.S. private, 0 if not) and $X 9=$ Canadian university ( 1 if Canadian, 0 if not). Finally, we include a time trend in the regression as a rough way of partially accounting for factors outside the university that may increase the costs of meeting a given level of demand for the library's services (such as serials inflation or rising salaries).

To test the hypothesis we analyze 11 years of data from 1992 through 2003 for 113 libraries that are members of the ARL, yielding a total of 1,190 observations. ARL libraries not examined include nonuniversity libraries and a small number of institutions that were dropped due to missing data. The ARL data set is selected because this is a widely recognizable and complete longitudinal data set that represents a relatively homogeneous population.

We regress the natural logarithm of total real library expenditures $(\mathrm{Y})$ on the logs of undergraduate enrollment, graduate enrollment, number of teaching faculty, number of Ph.D. fields and number of Ph.D.s awarded annually. The use of a logarithmic rather than linear model allows the estimated marginal impact of a change in an independent variable to diminish. For example, the impact on cost from adding the 90th Ph.D. program is probably less than the impact on cost of adding the 20th. Also included in the regression are a time trend, a constant term and indicator variables for: presence of a medical school, presence of a law school, public/private status, and Canadian/American affiliation. 


\begin{tabular}{|l|c|}
\hline \multicolumn{2}{|c|}{ TABLE 1 } \\
Coefficient of Measurables \\
\hline \hline Independent Variable & $\begin{array}{c}\text { Regression } \\
\text { Coefficient } \\
\text { (t-ratio) }\end{array}$ \\
\hline Log of Undergraduate Student Population & $0.037(1.908)$ \\
\hline Log of Graduate Student Population & $0.071(4.284)$ \\
\hline Log of Number of Ph.D.s Awarded & $0.049(3.511)$ \\
\hline Log of Number of Ph.D. Fields Offered & $0.004(0.291)$ \\
\hline Log of Number of Faculty & $0.071(6.051)$ \\
\hline Medical School (=1 if present, 0 if not) & $0.086(5.319)$ \\
\hline Law School (=1 if present, 0 if not) & $0.123(5.421)$ \\
\hline Private (=1 if U.S. private, 0 otherwise) & $0.212(3.773)$ \\
\hline Canadian (=1 if Canadian, 0 otherwise) & $-0.216(-2.882)$ \\
\hline Trend (=1,2,...,11 by year) & $0.024(34.613)$ \\
\hline Constant & $14.637(60.837)$ \\
\hline Lagrange multiplier test vs. OLS & $4,170.88$ \\
\hline R-squared & 0.489 \\
\hline Sample Size & 1190 \\
\hline $\begin{array}{l}\text { Note: The dependent variable is the natural logarithm of } \\
\text { total real expenditures. }\end{array}$ \\
\hline
\end{tabular}

\section{Results}

The estimated model is summarized in table 1. Coefficients of the operational indicators of demand for library services take the expected positive sign, and most are statistically significant at the five percent level or less in a two-tail test. The t-ratio for undergraduate enrollment is 1.908, slightly below the five-percent critical value, and there appears to be no significant association between funding and the number of Ph.D. programs after controlling for other independent variables. The model produces a coefficient of determination $\left(\mathrm{R}^{2}\right)$ of .489, indicating a modicum of correlation between the independent variables and library funding. A "Lagrange multiplier" test of the random effects model against an ordinary least-squares model that ignores persistent library-specific fac-

A "random effects" model is used to account for unobserved library-specific factors that persist through time. Examples of such factors would be a large library endowment, costly special collections or archives, multiple branches, or any other unmeasured variable specific to a library with an ongoing impact on spending. By accounting for effects of persistent, unobserved library-specific factors, the random effects model recognizes that the observations are not all independent, since each library is observed repeatedly over the years. This feature allows for more efficient estimation (that is, lower standard errors) than would be obtained by estimators that ignored unmeasured library-specific factors. Intuitively, the model assumes that the funding response to a change in an independent variable is the same for all libraries, but the base level of funding may vary due to library-specific factors. The model is estimated by generalized least squares. tors yields a chi-square test statistic with one degree of freedom of 4,171, providing strong support for the importance of accounting for library-specific effects.

The coefficient of a logarithmic variable measures the estimated "elasticity," or the percentage change in total real expenditure associated with a one percent change in the independent variable. All of the estimated elasticities are well below unity, indicating that one percent changes in independent variables are associated with much smaller than one percent increases in library funding. For example, the largest elasticity estimates of .071 indicate that a one percent increase in graduate student enrollment or in the number of teaching faculty is associated with about a 7/100 of one percent increase in total real expenditure. That these estimates, as well as the elasticity for Ph.D.s awarded, are larger than the elasticity for undergraduate enrollment should not be surprising given the relatively greater investment in library resources required by research 
and graduate education. Coefficients of indicator variables when multiplied by 100 approximate the percentage change in total real expenditure associated with presence of the indicator. Thus, presence of a medical school is associated with 8.6 percent greater expenditure, and presence of a law school is associated with 12.3 percent greater expenditure. Libraries associated with private universities in the United States spend about 21 percent more than their public counterparts in the United States, while Canadian university libraries spend about 21 percent less on average than U.S. public university libraries. The coefficient of the trend variable represents the average year-to-year growth in expenditures when holding all independent variables constant and reflects the influence of factors like serials inflation or real increases in salaries. According to the model, expenditures increase on average by 2.4 percent annually, holding other independent variables constant.

Researchers seeking a more parsimonious model might consider whether all three of the independent variables measuring graduate enrollment, number of Ph.D. degrees awarded and number of Ph.D. fields should be included, as they correlate highly with one another. Pearson correlation coefficients between pairs of these variables range from 0.65 to 0.76 . While Pearson correlation is useful for assessing linear relationships between pairs of variables, the "condition number" of the data matrix indicates whether more general linear relationships between multiple variables are problematic. ${ }^{12}$ The condition number computed for the data matrix (the ratio of the largest to the smallest characteristic root of the normalized cross-product matrix) is 10.59 , well below the value of 20 that Belsley, Kuh, and Welsch suggest as indicating a potential collinearity problem.

\section{Application to a Specific Institution}

Table 2 shows an application of the formula to an actual set of data for a rapidly growing university in the south that is not an ARL member. Based on changes in the independent variables, the formula produces a relatively modest increase of $\$ 364,903$ in library funding. There is, however, also an underlying rate of growth in university library budgets independent of growth in these campus independent variables. This trend growth, produced from the aforementioned trend variable, is what the library would have experienced on average with no growth in the

\begin{tabular}{|c|c|c|c|c|c|c|c|}
\hline \multicolumn{8}{|c|}{$\begin{array}{c}\text { TABLE } 2 \\
\text { Application of Model to a University }\end{array}$} \\
\hline & & & & Trend & 0.024 & & \\
\hline & & & & Base: & $\$ 10,000,000$ & & \\
\hline & $\begin{array}{l}\text { Year } \\
2002\end{array}$ & $\begin{array}{l}\text { Year } \\
2003\end{array}$ & $\begin{array}{c}\% \\
\text { Change }\end{array}$ & $\mathrm{X} 100$ & Elasticity & $\begin{array}{c}\% \\
\text { Impact }\end{array}$ & $\begin{array}{c}\text { Change } \\
\text { in } \\
\text { Funding }\end{array}$ \\
\hline Faculty & 976 & 1,050 & 0.076 & 7.58 & $0.0710 \%$ & 0.0054 & $\$ 53,832$ \\
\hline Undergrads & 22,054 & 25,799 & 0.170 & 16.98 & $0.0370 \%$ & 0.0063 & $\$ 62,830$ \\
\hline Grad Students & 2,066 & 2607 & 0.262 & 26.19 & $0.0710 \%$ & 0.0186 & $\$ 185,920$ \\
\hline Number Ph.D.s & 87 & 97 & 0.115 & 11.49 & $0.0490 \%$ & 0.0056 & $\$ 56,322$ \\
\hline Ph.D. Fields & 20 & 23 & 0.150 & 15.00 & $0.0040 \%$ & 0.0006 & $\$ 6,000$ \\
\hline Total change & & & & & & & $\$ 364,903$ \\
\hline Trend growth & & & & & & & $\$ 240,000$ \\
\hline Overall change & & & & & & & $\$ 604,903$ \\
\hline As percent & & & & & & & $6.05 \%$ \\
\hline
\end{tabular}




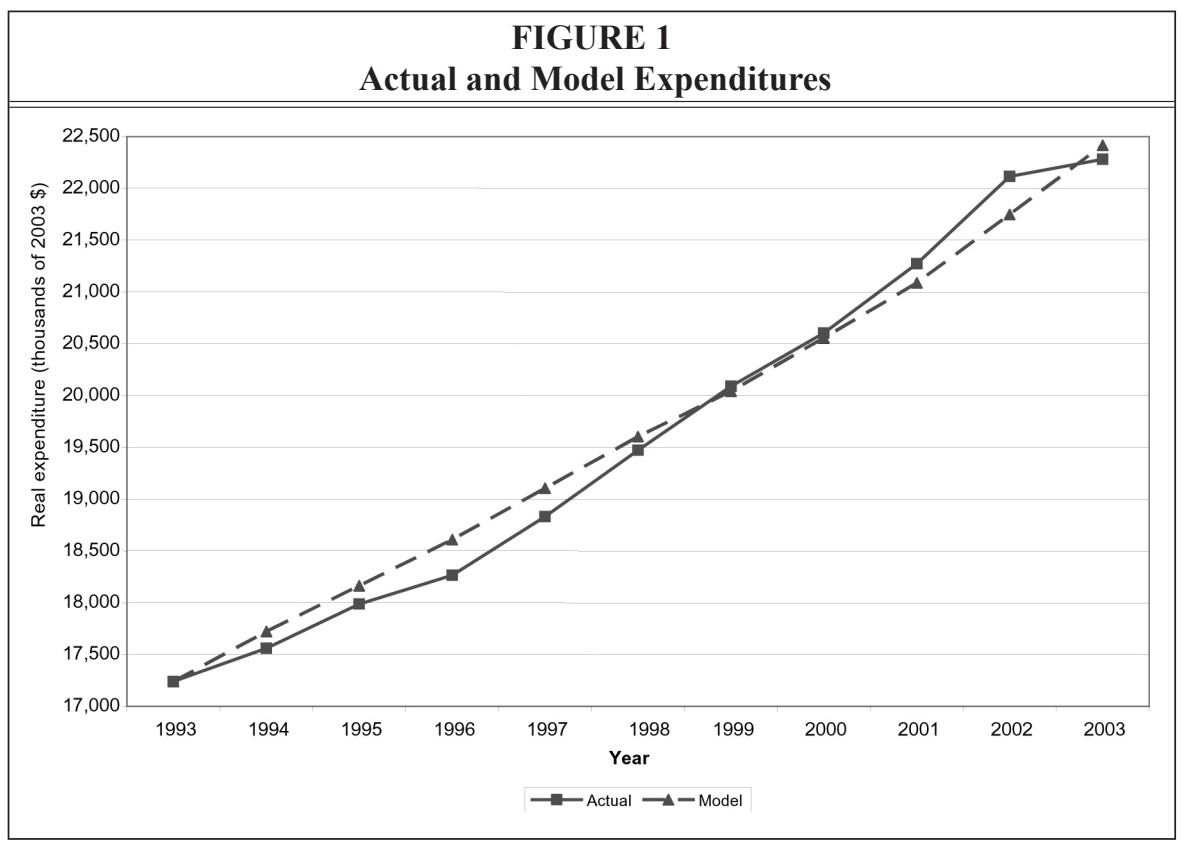

independent variables. In the example above, the increase from applying the trend variable yields $\$ 240,000$. The total increase suggested from the formula is $\$ 604,903$, a 6.05 percent rate of growth.

\section{Application to Expenditure Growth over Time}

A second application of the model is to compare the time path of actual expenditures of a library or set of libraries to the time path of expenditures predicted by the model. Figure 1 illustrates this type of comparison for the 99 libraries having complete data for each of the 11 years. The solid line plots the average of the 99 libraries' total real expenditures in each year, while the dashed line shows the average real expenditure predicted by the model in table 1 . To simplify the comparison, the model-predicted expenditure is adjusted so that it matches the actual expenditure in the first year. As shown, the average library experienced erratic transitory swings in its expenditure growth rate, namely the dip in the mid 1990s and the pronounced slowing in year 2002-2003. In contrast, a hypo- thetical library with the same starting level of expenditures in 1993 but funded according to the model (represented by the dashed line) would experience a much steadier and more predictable rate of budget growth.

\section{Application across Libraries}

The model can be applied in a third way by comparing a library's actual spending against the hypothetical spending that the model suggests. Table 3 provides this comparison for the ARL libraries that formed the data set for this study. The Actual column shows the library's average annual total expenditures, as reported in the ARL statistics, for the 11-year period, in 2003 U.S. dollars. The Model column shows the library expenditures predicted by the model, based upon the averages of the independent variables for that institution for the 11 years of data. The difference between these two produces an Over Predicted or Under Predicted amount based upon the methodology of the model. To argue that these terms are synonymous with "overfunded" and "underfunded" would be presumptuous; however, the 
suggestion is worth exploring on a comparative basis. Static results that are of limited value for one institution might be useful in comparing a library against a cohort group of peers. For example, three of the ten libraries with the largest excess of actual over model-predicted funding are at Ivy League institutions (Harvard, Yale, Princeton) and two are in the UC system (Berkeley and UCLA). Only one Ivy League library (Brown) and two of seven of the included UC-system libraries (Davis and Riverside) have actual funding below model-predicted funding

\section{Limitations to the Model}

There are a number of limitations to this research. There is no separate enumeration of independent sources of funding such as endowments, or of important cost drivers such as archives, special collections, and multiple library branches (although the net effect of all persistent library-specific factors is implicitly accounted for in the random effects model). The analysis does not account for the myriad of preservation and digitization efforts underway in libraries. The model may be more useful for growing institutions and less useful for institutions in a steady state of existence. Last, the formula does not explicitly estimate the impact of serials inflation but only accounts for it indirectly through the trend variable.Practical applications of formulabased allocation schemes should account more directly for the funding necessities born from serials inflation.

\section{Further Study}

If the goal were to make this model truly practical and more applicable, one might consider other possible independent variables. Libraries can argue that there should be a correlation between research grant money flowing into the institution and the library's budget. A more ambitious extension would be to measure the amount of scholarly productivity for the universities under study and use this to create an independent variable that would factor the number or quality of scholarly publications into the model. Both of these ideas suggest that the greater the university's rate of research and publication, the more money should flow into the library to support research. This approach turns the notion of the size of the library as a measure of its "goodness" on its head. At least one study in the library literature suggests that a university library's collection helps shape the university's reputation. Lewis Liu provides empirical evidence that the library's ARL ranking correlates closely with its U.S. News and World Report ranking. ${ }^{13}$ This may be true; however it should be noted that U.S. News and World Report includes library funding per student as a metric in its ranking of colleges and universities. In any case, the extensions to the analysis proposed here suggest the opposite relationship: that a university that is demonstrating growth in research activity should support its faculty by building a stronger library through increased financial support. This is a subtle but important distinction, which moves the debate away from measuring the goodness of the library by input measures (volume count, number of serials, expenditures, etc.) to a model that suggests that the library should be strong to reflect the level of research taking place at the university.

\section{Conclusion}

The purpose of the study is not to create a one-size-fits-all model for funding. The model illustrates a foundation for what could evolve into funding strategies based upon measurable inputs. Easily measurable inputs or drivers can potentially shield the library from arbitrary cuts. An institution can devise its own set of measurable inputs. Is the model a good thing or a bad thing for libraries? Libraries with exceptional influence on campus may find no benefit to such an approach. Libraries faced with political disadvantages or distinct underfunding relative to peer institutions may be able to use this approach to their benefit.

Does increased library funding even necessarily convey additional benefit to 


\begin{tabular}{|c|c|c|c|c|}
\hline $\begin{array}{r}\text { Actual Expenditures, Moc } \\
\text { Perce }\end{array}$ & $\begin{array}{l}\text { TABLE } \\
\text { enditure } \\
\text { f Model: }\end{array}$ & and 0 & $\begin{array}{l}\text { er or Und } \\
\text { Year }\end{array}$ & Predicted as \\
\hline & Thousan & s of 2003 & S Dollars & \\
\hline University & Actual & Model & Difference & $\begin{array}{l}\text { Percent Over } \\
(+) \text { or Under }(-) \\
\text { Predicted }\end{array}$ \\
\hline ALABAMA & 10,870 & 16,512 & $-5,642$ & $-34 \%$ \\
\hline ALBERTA & 18,402 & 15,061 & 3,342 & $23 \%$ \\
\hline ARIZONA & 22,400 & 19,898 & 2,502 & $12 \%$ \\
\hline ARIZONA STATE & 21,972 & 18,461 & 3,510 & $19 \%$ \\
\hline AUBURN & 10,399 & 13,835 & $-3,436$ & $-25 \%$ \\
\hline BOSTON & 14,848 & 24,051 & $-9,203$ & $-38 \%$ \\
\hline BOSTON COLLEGE & 15,884 & 19,655 & $-3,771$ & $-19 \%$ \\
\hline BRIGHAM YOUNG & 16,073 & 17,318 & $-1,245$ & $-7 \%$ \\
\hline BRITISH COLUMBIA & 22,254 & 15,891 & 6,362 & $41 \%$ \\
\hline BROWN & 15,711 & 15,798 & -87 & $0 \%$ \\
\hline CALIFORNIA, BERKELEY & 42,217 & 19,251 & 22,966 & $119 \%$ \\
\hline CALIFORNIA, DAVIS & 18,982 & 19,598 & -616 & $-3 \%$ \\
\hline CALIFORNIA, IRVINE & 16,691 & 15,695 & 996 & $6 \%$ \\
\hline CALIFORNIA, LOS ANGELES & 39,396 & 21,871 & 17,526 & $81 \%$ \\
\hline CALIFORNIA, RIVERSIDE & 10,322 & 12,427 & $-2,105$ & $-17 \%$ \\
\hline CALIFORNIA, SAN DIEGO & 20,720 & 15,960 & 4,760 & $30 \%$ \\
\hline CALIFORNIA, SANTA BARBARA & 14,553 & 14,124 & 429 & $3 \%$ \\
\hline CASE WESTERN RESERVE & 11,414 & 21,098 & $-9,684$ & $-46 \%$ \\
\hline CHICAGO & 23,378 & 22,871 & 507 & $2 \%$ \\
\hline CINCINNATI & 17,082 & 18,828 & $-1,746$ & $-9 \%$ \\
\hline COLORADO & 17,526 & 15,710 & 1,816 & $12 \%$ \\
\hline COLORADO STATE & 11,630 & 14,058 & $-2,427$ & $-18 \%$ \\
\hline COLUMBIA & 35,062 & 25,059 & 10,003 & $40 \%$ \\
\hline CONNECTICUT & 19,677 & 18,347 & 1,330 & $8 \%$ \\
\hline CORNELL & 34,170 & 22,372 & 11,798 & $52 \%$ \\
\hline DARTMOUTH & 14,118 & 15,702 & $-1,584$ & $-10 \%$ \\
\hline DELAWARE & 13,040 & 13,574 & -534 & $-4 \%$ \\
\hline DUKE & 25,969 & 22,013 & 3,956 & $18 \%$ \\
\hline EMORY & 24,691 & 20,702 & 3,988 & $18 \%$ \\
\hline FLORIDA & 22,267 & 21,247 & 1,020 & $4 \%$ \\
\hline FLORIDA STATE & 12,363 & 17,506 & $-5,143$ & $-29 \%$ \\
\hline GEORGE WASHINGTON & 17,475 & 22,471 & $-4,996$ & $-23 \%$ \\
\hline GEORGIA & 19,672 & 18,200 & 1,473 & $8 \%$ \\
\hline GEORGIA TECH & 8,820 & 13,854 & $-5,034$ & $-36 \%$ \\
\hline HARVARD & 83,090 & 25,112 & 57,978 & $230 \%$ \\
\hline HAWAII & 13,023 & 13,942 & -919 & $-6 \%$ \\
\hline
\end{tabular}




\begin{tabular}{|c|c|c|c|c|}
\hline \multicolumn{5}{|c|}{$\begin{array}{c}\text { TABLE } 3 \\
\text { Actual Expenditures, Model Expenditures, and Over or Under Predicted as } \\
\text { Percentage of Model: Average Year }\end{array}$} \\
\hline \multirow[b]{2}{*}{ University } & \multicolumn{3}{|c|}{ Thousands of 2003 US Dollars } & \multirow[b]{2}{*}{$\begin{array}{l}\text { Percent Over } \\
(+) \text { or Under (-) } \\
\text { Predicted }\end{array}$} \\
\hline & Actual & Model & Difference & \\
\hline HOUSTON & 12,779 & 16,443 & $-3,664$ & $-22 \%$ \\
\hline HOWARD & 12,269 & 20,098 & $-7,829$ & $-39 \%$ \\
\hline ILLINOIS, CHICAGO & 16,297 & 16,979 & -682 & $-4 \%$ \\
\hline ILLINOIS, URBANA & 28,473 & 19,592 & 8,881 & $45 \%$ \\
\hline INDIANA & 27,385 & 18,103 & 9,282 & $52 \%$ \\
\hline IOWA & 20,907 & 19,064 & 1,844 & $9 \%$ \\
\hline IOWA STATE & 15,062 & 15,038 & 24 & $0 \%$ \\
\hline JOHNS HOPKINS & 24,128 & 19,165 & 4,963 & $26 \%$ \\
\hline KANSAS & 16,973 & 19,109 & $-2,136$ & $-11 \%$ \\
\hline KENT STATE & 10,974 & 13,540 & $-2,566$ & $-19 \%$ \\
\hline KENTUCKY & 17,996 & 18,321 & -325 & $-2 \%$ \\
\hline LAVAL & 12,378 & 15,297 & $-2,919$ & $-18 \%$ \\
\hline LOUISIANA STATE & 11,367 & 17,027 & $-5,661$ & $-33 \%$ \\
\hline LOUISVILLE & 16,519 & 19,189 & $-2,671$ & $-14 \%$ \\
\hline MCGILL & 15,639 & 15,546 & 93 & $1 \%$ \\
\hline MCMASTER & 9,557 & 11,599 & $-2,043$ & $-17 \%$ \\
\hline MANITOBA & 10,688 & 13,550 & $-2,862$ & $-21 \%$ \\
\hline MARYLAND & 18,769 & 16,424 & 2,345 & $14 \%$ \\
\hline MASSACHUSETTS & 12,337 & 14,357 & $-2,019$ & $-14 \%$ \\
\hline MIT & 14,808 & 18,253 & $-3,446$ & $-19 \%$ \\
\hline MIAMI & 15,430 & 21,635 & $-6,205$ & $-29 \%$ \\
\hline MICHIGAN & 39,918 & 22,588 & 17,330 & $76 \%$ \\
\hline MICHIGAN STATE & 17,916 & 16,816 & 1,099 & $6 \%$ \\
\hline MINNESOTA & 30,511 & 20,646 & 9,865 & $48 \%$ \\
\hline MISSOURI & 13,001 & 18,298 & $-5,297$ & $-29 \%$ \\
\hline MONTREAL & 16,296 & 18,180 & $-1,884$ & $-10 \%$ \\
\hline NEBRASKA & 12,112 & 16,331 & $-4,220$ & $-26 \%$ \\
\hline NEW MEXICO & 18,547 & 17,400 & 1,147 & $7 \%$ \\
\hline NEW YORK & 29,357 & 25,690 & 3,666 & $15 \%$ \\
\hline NORTH CAROLINA & 25,944 & 20,314 & 5,630 & $28 \%$ \\
\hline NORTH CAROLINA STATE & 19,014 & 14,934 & 4,080 & $26 \%$ \\
\hline NORTHWESTERN & 21,047 & 24,191 & $-3,145$ & $-13 \%$ \\
\hline NOTRE DAME & 15,925 & 18,264 & $-2,339$ & $-14 \%$ \\
\hline OHIO & 12,241 & 15,715 & $-3,474$ & $-22 \%$ \\
\hline OHIO STATE & 25,372 & 22,242 & 3,130 & $14 \%$ \\
\hline OKLAHOMA & 12,206 & 17,147 & $-4,941$ & $-29 \%$ \\
\hline
\end{tabular}




\begin{tabular}{|c|c|c|c|c|}
\hline \multicolumn{5}{|c|}{$\begin{array}{c}\text { TABLE } 3 \\
\text { Actual Expenditures, Model Expenditures, and Over or Under Predicted as } \\
\text { Percentage of Model: Average Year }\end{array}$} \\
\hline \multirow[b]{2}{*}{ University } & \multicolumn{3}{|c|}{ Thousands of 2003 US Dollars } & \multirow[b]{2}{*}{$\begin{array}{l}\text { Percent Over } \\
(+) \text { or Under (-) } \\
\text { Predicted }\end{array}$} \\
\hline & Actual & Model & Difference & \\
\hline OKLAHOMA STATE & 10,368 & 15,262 & $-4,894$ & $-32 \%$ \\
\hline OREGON & 13,140 & 15,369 & $-2,229$ & $-14 \%$ \\
\hline PENNSYLVANIA & 28,942 & 24,911 & 4,031 & $16 \%$ \\
\hline PENNSYLVANIA STATE & 33,508 & 20,321 & 13,188 & $65 \%$ \\
\hline PITTSBURGH & 22,283 & 19,753 & 2,530 & $13 \%$ \\
\hline PRINCETON & 29,226 & 16,088 & 13,138 & $82 \%$ \\
\hline PURDUE & 14,251 & 16,331 & $-2,080$ & $-13 \%$ \\
\hline QUEEN'S & 10,395 & 13,161 & $-2,767$ & $-20 \%$ \\
\hline RICE & 13,502 & 14,528 & $-1,026$ & $-8 \%$ \\
\hline ROCHESTER & 12,658 & 17,292 & $-4,634$ & $-27 \%$ \\
\hline RUTGERS & 28,018 & 18,619 & 9,399 & $51 \%$ \\
\hline SASKATCHEWAN & 9,055 & 12,983 & $-3,928$ & $-30 \%$ \\
\hline SOUTH CAROLINA & 15,956 & 18,292 & $-2,336$ & $-13 \%$ \\
\hline SOUTHERN CALIFORNIA & 24,929 & 25,123 & -194 & $-1 \%$ \\
\hline SOUTHERN ILLINOIS & 12,657 & 15,706 & $-3,048$ & $-19 \%$ \\
\hline STANFORD & 53,723 & 24,130 & 29,593 & $121 \%$ \\
\hline SUNY-ALBANY & 10,530 & 12,988 & $-2,459$ & $-19 \%$ \\
\hline SUNY-BUFFALO & 16,153 & 18,823 & $-2,670$ & $-14 \%$ \\
\hline SUNY-STONY BROOK & 12,237 & 15,959 & $-3,722$ & $-23 \%$ \\
\hline SYRACUSE & 12,154 & 19,253 & $-7,099$ & $-37 \%$ \\
\hline TEMPLE & 13,181 & 18,841 & $-5,659$ & $-30 \%$ \\
\hline TENNESSEE & 15,399 & 17,681 & $-2,282$ & $-13 \%$ \\
\hline TEXAS & 30,418 & 20,665 & 9,753 & $47 \%$ \\
\hline TEXAS A\&M & 20,744 & 18,776 & 1,968 & $10 \%$ \\
\hline TEXAS TECH & 15,337 & 19,073 & $-3,736$ & $-20 \%$ \\
\hline TORONTO & 38,465 & 17,260 & 21,205 & $123 \%$ \\
\hline TULANE & 11,607 & 20,490 & $-8,883$ & $-43 \%$ \\
\hline UTAH & 19,466 & 18,058 & 1,408 & $7 \%$ \\
\hline VANDERBILT & 17,031 & 21,965 & $-4,934$ & $-22 \%$ \\
\hline VIRGINIA & 24,683 & 18,668 & 6,015 & $32 \%$ \\
\hline VPI \& SU & 12,178 & 15,427 & $-3,249$ & $-21 \%$ \\
\hline WASHINGTON & 29,972 & 21,701 & 8,271 & $39 \%$ \\
\hline WASHINGTON STATE & 12,231 & 13,996 & $-1,765$ & $-13 \%$ \\
\hline WASHINGTON U.-ST. LOUIS & 21,984 & 20,676 & 1,308 & $5 \%$ \\
\hline WATERLOO & 9,444 & 10,658 & $-1,213$ & $-11 \%$ \\
\hline WAYNE STATE & 17,683 & 18,427 & -744 & $-4 \%$ \\
\hline
\end{tabular}


TABLE 3

Actual Expenditures, Model Expenditures, and Over or Under Predicted as Percentage of Model: Average Year

\begin{tabular}{|l|r|r|r|c|}
\hline \multirow{2}{*}{ University } & \multicolumn{3}{|c|}{ Thousands of 2003 US Dollars } & \\
\hline & \multicolumn{1}{|c|}{ Actual } & \multicolumn{1}{c|}{ Model } & Difference & $\begin{array}{c}\text { Percent Over } \\
(+) \\
\text { or Under ( } \\
\text { Predicted }\end{array}$ \\
\hline WESTERN ONTARIO & 12,497 & 13,113 & -616 & $-4 \%$ \\
\hline WISCONSIN & 32,378 & 21,869 & 10,510 & $48 \%$ \\
\hline YALE & 47,174 & 23,299 & 23,876 & $102 \%$ \\
\hline YORK & 14,115 & 11,805 & 2,310 & $20 \%$ \\
\hline
\end{tabular}

the institution? Assuming that the institution's budget process is a zero sum game, gains in library funding reduce funding elsewhere. It is well beyond the scope of this study to compare the marginal utility of dollars steered toward the library versus other programs on campus. However, in the cases of obvious underfunding one might argue that the utility of marginal dollars allocated to the severely under- funded library may be high (i.e., a good investment by the institution).

Last, the model may also serve to move the debate for funding away from traditional input measures and toward a broader set of institutionally based output indicators. This approach may be favorably received as universities as a whole move more toward outcomesbased planning.

\section{Notes}

1. David Baker, "Resource Allocation in University Libraries," The Journal of Documentation 48 (Mar. 1992): 1-19.

2. Frank W. Goudy, "Academic Libraries and the Six Percent Solution: A Twenty-Year Financial Overview," Journal of Academic Librarianship 19 (Sept. 1993): 212-15.

3. Association of College and Research Libraries, "Standards for Libraries in Higher Education," College \& Research Libraries News 65 (Oct. 2004): 534-43. Available online from www.ala. org/ala/acrl/acrlstandards/standardslibraries.htm. [Accessed 15 September 2005].

4. Kendon Stubbs, "Trends in University Funding for Research Libraries," ARL: A Bimonthly Newsletter of Research Library Issues and Actions 172 (Jan. 1994).

5. Rolf Griebel, "University Library Budgets - Model and Reality," New Review of Academic Librarianship 2 (1996): 59-67.

6. Murle E. Kenerson, "Performance Funding and Full-Time Equivalence: Implications for Funding in Academic Libraries," 13 (1996). ERIC, ED398927.

7. Jin-Chuan Ma, "Fund Allocations for Information Resources in China's Key Universities," College \& Research Libraries 60 (Mar. 1999): 174-78.

8. Peter A. Facione, "The Philosophy and Psychology of Effective Institutional Budgeting," Academe 88 (Nov./Dec. 2002): 45-48.

9. Jim Tolhurst, "Resource Allocation and Budgeting," Journal of Tertiary Educational Administration 7 (Oct. 1985): 143-55.

10. Nancy Cantor and Paul N. Courant, "Scrounging for Resources: Reflections of the Whys and Wherefores of Higher Education Finance," New Directions for Institutional Research 119 (Fall 2003): 3-12.

11. Gunapala Edirisooriya, "State Funding of Higher Education: A New Formula," Higher Education Policy 16 (Mar. 2003): 121-33.

12. David A. Belsley, Edwin Kuh, and Roy E. Welsch, Regression Diagnostics: Identifying Influential Data and Sources of Collinearity. (New York: John Wiley and Sons, 1980).

13. Lewis G. Liu, "The Economic Behavior of Academic Research Libraries: Toward a Theory," Library Trends 51 (Winter 2003): 277-92. 


\section{A unique source of historical reference for nearly 250 years - delivering analyses and context for today's headlines}

$1 /$ ence for a bird's-eye view of what happened in the world during a given year...The strength of the publication lies in analysis, interpretation, and overviews."

- American Reference Books Annual 1999

"This timely compendium covers the major economic, social, and cultural events... Cited in Sheehy and BCL 3."

- Reference \& Research Book News

"Continues its tradition of excellence... Published since 1758 , this source has proven its usefulness over time." - American Reference Books Annual 2004

"The writing is good and the authors are clearly experts. Exhaustive and thorough." - American Reference Books Annual 2001

For this new edition, over 80 contributors - headed by the eminent historian Philip M.H. Bell - combine their expert knowledge with singular clarity in style. They cover:

- 209 countries - more than the total membership of the UN. Provides quick-reference data for every country in the world.

- Trends in: science and the consequences of global climate change; the international economy; religion, law, and the arts.

\section{Special prepublication offer!}

$\$ 210$ or $£ 150$, plus shipping, until 12/31/06; thereafter, $\$ 233$ or $£$ 166.40. Available through your vendor.

The Annual Register, 247th Edition: World Events. Edited by D.S. Lewis \& Wendy Slater. Overview by Philip M.H. Bell, with 83 author/contributors. ISBN 1-60030-069-3. 626 pp., incl. 4color photographs, maps, tables, and index, hardbound. 